\title{
How Do They Feel at the First Line During the Covid Outbreak: A Survey among Indonesian Nurses
}

\author{
Ardia Putra ${ }^{1} \mathbb{D}$, Yuswardi Yuswardi ${ }^{1}$, Nurhasanah Nurhasanah ${ }^{2 *}$ (D) \\ ${ }^{1}$ Department of Nursing Management, Faculty of Nursing, Universitas Syiah Kuala, Banda Aceh, Indonesia; ${ }^{2}$ Department of \\ Nursing Geriatric, Faculty of Nursing, Universitas Syiah Kuala, Banda Aceh, Indonesia
}



Abstract

AIM: This descriptive survey study is conducted to examine the nurses' perceived occupational safety as a front line during the pandemic period in Aceh Province, Indonesia

METHODS: This research used a cross-sectional study design. The study was conducted in all districts/cities in the Aceh province. Sample in this study amounted to 199 respondents, collected using a snowball sampling technique. The developed questionnaire consists of respondents' demographic data and Nurse Occupational Safety Questionnaire, and it has been tested for validity and reliability tests. Data were collected using web-based questionnaires (google form) via appointed representatives responsible for sharing the questionnaire link. Then, data were analyzed using the descriptive statistic by using SPSS software.

RESULTS: This study found that 126 respondents (63.3\%) perceived safe and 73 respondents $(33.7 \%)$ felt the unsafe conditions in working during pandemic in Aceh. Factors contributed to this result are included age $(p=0.029)$, educational level $(p=0.003)$, and work setting $(p=0.000)$.

CONCLUSION: Feeling unsafe by nurses can be assumed by the incidence rate of nurses becoming infected by the Severe Acute Respiratory Syndrome-Coronavirus-2 virus has reached $60.3 \%$ for the respondent. Therefore, the stakeholders, including the Government, Health Service Management, Hospital Management, and other health agencies, must take responsibility for this situation, especially in monitoring and evaluating the performance and needs of nurses who direct and indirectly treat the coronavirus disease 2019 patients.

\section{Introduction}

The coronavirus disease 2019 (Covid-19) pandemic is an event that has shocked the world since the end of 2019 due to the outbreak of a new type of coronavirus, namely Severe Acute Respiratory SyndromeCorona Virus-2 (SARS-CoV-2) [1], [2]. The spread of this epidemic is very fast, first appearing in Wuhan at the end of 2019 , and continues to spread very quickly throughout the country of China [3]. SARS-CoV-2 has spread rapidly worldwide to 215 countries and 163 countries with local transmission [4]. Moreover, Indonesia is one of the affected countries, with massive distribution to 456 districts/cities and local transmission in 182 regions [1].

Globally, Covid-19 sufferers have reached more than 17 million cases with a mortality rate of $3.86 \%$ [5]. Estimates based on data from the Centers for Disease Control and Prevention show that the SARS-CoV-2 virus has infected more than 150,000 hospitals and nursing home staff in the workplace, and over 700 people have died. However, the actual number is unknown due to an inadequate data surveillance system [6]. Indonesia ranks third in mortality (5\%) in Asia after India and Bangladesh [5].
The high number of deaths due to Covid-19 in Indonesia is a challenge for nurses in providing health and nursing services for the community [7]. In a pandemic situation, nurses are part of the front line controlling Covid-19, which is very risky and can even infect family members at home and the community [8]. Therefore, nurses should be provided with additional assistance in protecting themselves based on specific infection control procedures, including providing adequate personal protective equipment (PPE) in the workplace such as masks, robes, eye patches, face shields, and gloves [8]. In addition, guidance to nurses and support staff on COVID-19 issues and hazards must continue to be supported by nursing managers and instructors tailored to their respective fields of work [9]. Therefore, health service agencies must provide and implement strategic steps to protect all existing human resources, both from diseases and accidents due to work [7].

A work accident is an unexpected event that has to do with the work being undertaken [10], often caused by unsafe acts (human factor) and unsafe conditions (environmental element) [10], [11], and generally (85\%) caused by human factors with unsafe actions [12]. The survey results show that the causes of work accidents can be caused by: disasters (natural and non-natural) 
or other unavoidable and emergency matters by $3 \%$, then $24 \%$ due to environmental factors or equipment that does not meet standards, and another $73 \%$ due to unsafe behavior [11].

Based on statistical data in Indonesia, 80\% of work accidents occur due to unsafe action factors, and the rest are caused by unsafe conditions [13]. Unsafe action can occur due to hazardous attitudes and actions, lack of knowledge and skills, invisible body defects, fatigue, and lethargy [10], [14]. Meanwhile, unsafe conditions occur due to PPE and unsuitable work clothes, hazardous materials, inadequate ventilation and lighting, and hazardous and ineffective tools or machines [10], [14].

In the face of the biggest Covid-19 crisis in the history of the $20^{\text {th }}$ century, government agencies have not optimally fulfilled their responsibilities for the health and safety of health workers [15]. The Occupational Safety and Health Administration (OSHA) does not necessarily make the workplace safe, but it is the responsibility of every employer or workplace owner. By law, every worker has the right to a safe workplace, and OSHA's mission is to protect this right by ensuring that employers eliminate hazards that could injure workers or increase their risk of illness [15]. In this respect, the safety of nurses during the pandemic is vital for nurses as the front line of service, and this is the full responsibility of the Government and owners of health services (hospitals, public health centers [PHC], health clinics, and other agencies).

Currently, there is substantial confusion about the transmission methods of Covid-19, who is at risk of spreading or contracting the virus, and where it is spreading [9]. These misunderstandings may circulate in the media mainstream, on social media platforms, or in the community, and they may conflict with efforts to respond to public health concerns [6], [16]. Here, nurses have a critical function, as one of the leading healthcare teams, in providing public awareness about disease prevention and reducing the spread of myths about epidemics. In addition, nurses are also responsible for guiding people to available health services and supporting evidence-based initiatives to manage patients and reduce infections [6], [16].

However, many nurses experience physical, psychological, and social problems when facing uncertain conditions during a pandemic. Research from Cui et al. [17] in the emergency unit at the hospital ( $n=453$ nurses) revealed that many nurses experienced psychological impacts due to Covid-19. Common symptoms felt are anxiety and stress from mild to severe levels. In addition, the spread of the COVID-19 disease outbreak has caused a lot of uncertainty, anxiety, and panic; even nurses often experience conflicts such as discrimination and exclusion in the health care department [18].

In addition, when the Large-Scale Social Restrictions (PSBB in Indonesian) were relaxed, it also harmed controlling the spread of Covid-19. This government policy affects negligence and neglect of health protocols [1]. As a result, the number of positive confirmed cases of Covid-19 continues to increase. Data on the Covid-19 Report site on September 15, 2021, recorded the number of health workers who died from Covid-19 in Indonesia as many as 2,029 people. Of this number, 730 people (35.9\%) work as doctors, 667 people $(32.8 \%)$ work as nurses, and the rest are gathered from various other health workers such as dentists, midwives, pharmacists, and other health support personnel [19].

The high number of cases infected with Covid-19 in all parts of the world, and the high death rate, which reaches $5 \%$ of the total number of cases in Indonesia [5], is a big challenge for nurses in providing health services during this pandemic. Many nurses have lost their lives due to the Covid-19 virus. Therefore, this research is aimed to examine the level of nurses perceived occupational safety as a front line during the Covid-19 outbreak in Aceh Province, Indonesia.

\section{Materials and Methods}

A quantitative study using a cross-sectional approach to the study design is carried out. The population of this research is nurses who work in hospitals, PHC, health clinics, and other agencies from various cities/districts in Aceh, Indonesia. The sampling method used a snowball sampling technique, involving representatives from the DPW and DPD PPNI Aceh (Indonesian National Nurse Association). Data were collected for 2 months, August - September 2021. The sample willing to participate in this study was 199 people with various backgrounds (Table 1).

Table 1: Respondent demographic data $(n=199)$

\begin{tabular}{|c|c|c|}
\hline Demographic data & Frequency & $\%$ \\
\hline \multicolumn{3}{|c|}{ Age (years): $M i n-M a x=22-53, M=35.35 \pm 6.42$} \\
\hline 17-25 (Late teens) & 17 & 8.5 \\
\hline 26-35 (Early adulthood) & 96 & 48.2 \\
\hline 36-45 (Late adult) & 66 & 33.2 \\
\hline 46-55 (Early elder) & 20 & 10.1 \\
\hline \multicolumn{3}{|l|}{ Gender } \\
\hline Male & 96 & 48.2 \\
\hline Female & 103 & 51.8 \\
\hline \multicolumn{3}{|l|}{ Education } \\
\hline Magister & 15 & 7.5 \\
\hline Bachelor & 109 & 54.8 \\
\hline Diploma & 75 & 37.7 \\
\hline \multicolumn{3}{|c|}{ Long Working (Tahun): Min-Max=1-28, M=11.67 \pm 6.74} \\
\hline Establishment stage $(<2)$ & 14 & 7.0 \\
\hline Advancement stage $(2-10)$ & 80 & 40.2 \\
\hline Maintenance stage $(>10)$ & 105 & 52.8 \\
\hline \multicolumn{3}{|l|}{ Workplace } \\
\hline Hospital & 132 & 66.4 \\
\hline Public Health Center & 57 & 28.6 \\
\hline Health Clinic & 5 & 2.5 \\
\hline Educational Institution & 5 & 2.5 \\
\hline \multicolumn{3}{|l|}{ Employment status } \\
\hline Civil Employee (PNS) & 94 & 47.2 \\
\hline Non-Civil Employee (Non-PNS) & 105 & 52.8 \\
\hline \multicolumn{3}{|l|}{ Exposed/Infected with Covid 19} \\
\hline Never & 79 & 39.7 \\
\hline Once & 120 & 60.3 \\
\hline \multicolumn{3}{|l|}{ Work setting } \\
\hline Covid Area & 35 & 17.6 \\
\hline Non Covid Area & 164 & 82.4 \\
\hline
\end{tabular}


Data collection was performed by distributing web-based questionnaires (Google form) through appointed representatives. Each representative is responsible for sending survey link questionnaires (see Supplementary) to nurse members in each district/city, their respective area of responsibility. Researchers remind all representatives every week until the deadline for data collection.

The research instrument consists of 2 parts. First, it contains respondents' demographic data consisting of age, gender, education, length of work, workplace, employment status, ever/not exposed to Covid-19, and work settings. Second, the Nurse Occupational Safety Questionnaire (NOSQ/K3P) contains 30 question items (positive and negative questions) in the form of a Guttman scale. Alternative answer choices: Yes (score 2) and No (score 1) for positive questions. While for the negative questions, the score applies the other way.

The data is processed by following four steps: editing, coding, processing, and cleaning [20]. Statistical data were analyzed using computer software (IBM SPSS Statistics v.26). Categorization of nurses' perception of occupational safety as a front line during the pandemic in Aceh uses the "SAFE" category if the value is $x \geq$ Mean and "UNSAFE" if $x<$ Mean. Then, the percentage is used to determine the data resulting from the categorization [21]. Furthermore, the chi-square test was carried out for any potential factors that were thought to have a relationship with the results of this study.

Before this research was conducted, the researcher had gone through an ethical clearance process at the Research Ethics Commission, Faculty of Nursing, Universitas Syiah Kuala. The permit to conduct the research is stated in a letter numbered 113004170521. This permission is done to ensure the independence of the research results and ensure the confidentiality of all respondent data. In this web-based questionnaire, respondents received informed consent on the opening page. Each respondent has the same opportunity to be involved or refuse to be a respondent in this study without any coercion. Respondents can continue to fill in demographic data and answer all questions on the questionnaire after choosing "yes" and submitting the respondent's statement of consent. We ensure that the privacy and anonymity of respondents are well maintained by not including names.

\section{Results}

The distribution of respondents' demographic data in this study is presented in Table 1. In general, it can be concluded that almost half of the respondents are in the early adult age range, as many as 96 respondents $(48.2 \%)$, with female nurses as many as 103 respondents $(51.8 \%)$. The highest education level is Bachelor, which is 109 respondents (54.8\%), and the working period is in the maintenance stage ( $>10$ years) as many as 105 respondents $(52.8 \%)$, and non-PNS employment status as many as 105 respondents (52.8\%). Followed by 120 respondents $(60.3 \%)$ stating that they had been exposed to/infected with Covid-19, and 164 respondents (82\%) worked in non-Covid-19 area settings.

An overview regarding the nurse perceived occupational safety as a front line during the pandemic in Aceh shows that over half of the respondents, or up to 126 people (63.3\%), felt safe working as nurses during the pandemic in Aceh. The detail is shown in Table 2.

Table 2: Nurses perceived of occupational safety as a front line during the pandemic period in Aceh $(n=199)$

\begin{tabular}{lll}
\hline Category & Frequency & $\%$ \\
\hline Unsafe & 73 & 36.7 \\
Safe & 126 & 63.3 \\
\hline
\end{tabular}

Statistical analysis using the Chi-square test examined the contributing factors including age, education, and work setting with the nurses' perceived occupational safety as a front line during the pandemic period in Aceh, Indonesia. These three factors contributed to the result of the study, which includes age, education level, and work setting. The detail can be seen in Table 3.

Table 3: Factors contributing to nurses perceived of occupational safety as a front line during the pandemic period in Aceh ( $n=199 ; \alpha=0.05)$

\begin{tabular}{lllll}
\hline Contributing Factors & \multicolumn{2}{l}{$\begin{array}{l}\text { Nurses' perceived of occupational } \\
\text { safety }\end{array}$} & p-value \\
\cline { 2 - 4 } & Unsafe & Safe & Total & \\
\hline Age & 10 & 7 & 17 & \multirow{2}{*}{0.029} \\
$\quad$ Late teens & 26 & 70 & 96 & \\
Early adulthood & 29 & 37 & 66 & \\
$\quad$ Late adult & 8 & 12 & 20 & \\
$\quad$ Early elder & 37 & 38 & 75 & 0.003 \\
Education & 35 & 74 & 109 & \\
$\quad$ Diploma & 1 & 14 & 15 & \\
Bachelor & 3 & 32 & 35 & 0.000 \\
$\quad$ Magister & 70 & 94 & 164 & \\
Work setting & & & & \\
$\quad$ Covid Area & Non Covid Area & & &
\end{tabular}

\section{Discussion}

The study's finding (Table 2), in general, the nurses' perception of occupational safety, showed that 126 respondents $(63.3 \%)$ felt safe in terms of their safety when working as nurses on the front line during the Covid-19 pandemic in Aceh Province.

The essential occupational health and safety principle is a healthy, safe, and comfortable workplace and health facility for all medical personnel and other employees and patients and their families during treatment [22]. Nurses are professions that play an essential role in hospitals and other health care 
institutions-based on the number of nurses who have a significant share in health services. Nurses also have the most excellent contact with patients, visitors/families, and other health workers in carrying out their duties and functions [18]. Therefore, nurses play an essential role in implementing occupational safety management in hospitals and other health services, especially during the Covid-19 pandemic [1]. The objectives of work safety, especially during the Covid-19 pandemic, include: protecting the safety rights for workers (medical and paramedical); ensuring the safety of all people in the workplace environment; maintaining and using all sources of production safely and efficiently; and minimizing the causes of accidents and diseases due to work done [11].

Although the study results show that almost $2 / 3$ of respondents (63.3\%) perceived safe in occupational safety during this pandemic, more than $1 / 3$ of respondents (36.7\%) feel unsafe. Researchers assume the unsafe conditions felt by nurses can be caused by two general factors, namely unsafe action and unsafe conditions [10]. Several conditions are assumed correlated if traced in terms of unsafe action. That includes a physical imbalance of the workforce, doing a job without authority, lack of experience, misinterpreting an order, lack of skill, and wrong performing Standard Operational Procedure (SOPS) that has been determined; only pretending to use PPE, and workload or excessive hours [10], [11], [15]. This condition can be shown as 120 nurses/respondents (60.3\%) exposed/infected by Covid-19 (Table 1). Regardless of how vulnerable the nurse's duties are like the front line during the Covid-19 pandemic, so they can be exposed to the disease itself [8], unsafe action is the cause of work accidents with the percentage of events reaching $80-85 \%$ [10].

The transmission of Covid-19 infection is effortless because the cause is a microscopic virus, and a person can be infected by an airway [2]. An understanding of preventive measures is needed to prevent disease transmission. Efforts that must be made to minimize the risk of infection in hospitals and other health care facilities are infection prevention and control through a series of activities that include planning [23], implementation, coaching, education, training, and monitoring and evaluation [9], [24]. Furthermore, nurse compliance in implementing occupational safety guidelines can be influenced by various factors, including gender, age, education level, and work experience that has been passed [1].

This assumption is supported by the correlation test contained in Table 3 . Where in terms of age $(p=0.029)$ and education level $(p=0.003)$ respondents have a relationship with the results in this study. According to Stellman [25], individual characteristics such as age and education level significantly influence the incidence of accidents in the workplace. In addition, years of service, knowledge, gender, use of shift work methods, skills, physical condition, behavior, and attitudes of health workers also affect a person's ability [25]. Furthermore, Fadli et al. [26] also stated that health workers such as nurses and doctors tasked with preventing, handling, and caring for Covid-19 patients needed to employ a relatively young age range because they have better immunity. Taking care of Covid-19 patients will increase the high risk of contracting it for health workers, especially nurses in direct contact with patients [1], [26]. Therefore, high immunity, which young health workers generally own, is an important thing [1]. Following the study results where young nurses were the dominant respondents (late teen $=8.5 \%$ and early adulthood $=48.2 \%$ ), the age factor is assumed to provide a good sense of security for nurses in dealing with the Covid-19 pandemic in Aceh.

Furthermore, controlling the transmission of Covid-19 infection is very important. A qualitative study among Infection Prevention Control Link Nurse nurses ( $n=12$ ) emphasized that although the supervision related to infection control for old and new patients had been carried out well, there were still obstacles in the field. The barriers include some officers who were not obedient to using PPE and washing their hands [24]. Another factor that causes unsafe perceptions of nurses' occupational safety during the Covid-19 pandemic is generally caused by the hazardous condition [11]. The causes of hazardous conditions that are often found in the field/health care institutions include: equipment that is no longer suitable for use; limited availability of PPE; building security which is still below standard; inadequate lighting and ventilation; temperature conditions that can endanger the work; security conditions and warning systems that are not up to standard; and work in the health sector itself is widely blamed for causing potential dangers that threaten health workers, especially nurses [10], [11], [15].

Two unsafe condition factors as the cause of work accidents generally come from health service management, namely management factors and environmental factors [25]. Management factors consist of socialization of Occupational Safety and Health, policies, SOPs, and training [25]. Then environmental factors include ventilation, noise, lighting, housekeeping, color, and warning labels [11], [15], [25].

If seen from Table 3, generally, respondents work in non-covid areas (164 people/82.4\%). However, the incidence of being exposed/confirmed to be infected with Covid-19 for nurses occurred in 120 respondents $(60.3 \%)$. This condition should be of particular concern because unsafe conditions, especially for nurses who work in non-covid areas, reached 42.7\% (70/164 respondents). The chi-square test results also showed a significant relationship ( $p=0.000)$. In line with Romiko's research [27] which shows that eight nurses' abilities in preventing and controlling nosocomial infections are not under the rules according to WHO. The main cause is workplace conditions, nurse education, and 
work setting [27]. Additionally, the need for human resources, supporting tools, the convenience of supporting facilities, training/socialization, monitoring, evaluation, and coordination between units are the supporting factors for this problem [1], [27]. Therefore, nursing managers and instructors are required to provide direction to nurses and support staff about the problems and dangers of Covid-19 that arise according to their respective fields of work [9].

In addition, it is also necessary to increase enabling factors such as security and safety facilities and laws/rules so that the existing regulations influence the behavior of nurses in their environment [28]. Moreover, organizational culture can also affect nurses' behavior in work safety. A good organizational culture has a 2.652 times greater chance of having better behaviors in improving safety while working [29], especially during a pandemic.

\section{Conclusion}

Based on the research findings and discussion outlined above, it is possible to conclude that there are still $1 / 3$ of respondents $(33.7 \%)$ feel unsafe conditions in occupational safety as nurses during the pandemic in Aceh. Several factors that contributed to this result include age $(p=0.029)$, education level $(p=0.003)$ and work setting $(p=0.000)$.

The unsafe conditions felt by nurses in this study can be predicted by the incidence rate of the infected nurses by the SARS-CoV-2 virus has reached $60.3 \%$. Meanwhile, this study's respondents' workplace settings are generally non-covid areas (82.4\%). Therefore, the role of the Government through related agencies such as the Health Service Management, Hospital Management, and other health agencies needs to be improved, especially in monitoring and evaluating the performance and needs of nurses. Especially nurses who indirectly treat Covid-19 patients. Many complaints from respondents that infection prevention facilities, namely PPE (Hazmat clothes, masks, and others), are prioritized for health workers working in the Covid-19 area such as the Emergency Room and the NewEmerging and Re-Emerging Infectious Diseases Room. It shows the impression of failing to meet the prevention needs among inpatient rooms or other public health services who risk being exposed to the Covid-19 virus.

\section{Acknowledgment}

Thanks to FON-USK for facilitating the implementation of this research. Also, DPW PPNI
(Provincial) and DPD PPNI (Regency/City) in Aceh Province have supported data collection during this research.

\section{Supplementary}

Link of web-based questionnaire. https://docs. google.com/forms/d/e/1FAIpQLSd0A4x7RY-u5or9Xxb LQF9nHQdjB68FDBQ0soTDHPQ7pnRhRA/viewform.

\section{References}

1. Widani NL. The Nurse's Readiness Enters a New Release in the Covid-19 Pandemic. Vol. 00. STIK Sint Carolus-Jakarta; 2020. Available from: http://repository.stik-sintcarolus.ac.id/id/ eprint/985. [Last accessed on 2021 Nov 10].

2. Pakasi TA, Pakasi LS. The importance of environmental air control for prevention of transmission of SARS CoV2. CoMPH J Community Med Public Health Indones J. 2020;1(2):109-16.

3. Yuliana Y. Coronavirus diseases (Covid-19): A review of the literature. Wellness Health Mag. 2020;2(1):187-92.

4. World Health Organization. (World Health Organization Western Pasific Region). Materi Komunikasi Risiko COVID19 untuk Fasilitas Pelayanan Kesehatan. Geneva: World Health Organization; 2020. p. 1-11. Available from: https:// www.who.int/docs/default-source/searo/indonesia/covid19/riskcommunication-for-healthcare-facility.pdf?sfvrsn=9207787a_2. [Last accessed on 2021 Nov 10].

5. World Health Organization. Clinical Management of Severe Acute Respiratory Infection when Novel Coronavirus (2019nCoV) Infection is Suspected: Interim Guidance, Jan 282020. Geneva: World Health Organization; 2020. Available from: https://apps.who.int/iris/handle/10665/330893. [Last accessed on 2021 Nov 10]

6. Centers for Disease Control. Interim Guidance for the Use of Masks to Control Seasonal Influenza Virus Transmission. Atlanta: GA: Centers for Disease Control and Prevention; 2020. Available from: https://www.cdc.gov/flu/professionals/ infectioncontrol/maskguidance.htm. [Last accessed on 2021 Nov 10].

7. Ivana A, Widjasena B, Jayanti S. Analysis of hospital management commitment to occupational safety and health (K3) at Prima Medika Hospital Pemalang. J Kesehat Masy. 2014;2(1):35-41.

8. Adams JG, Walls RM. Supporting the health care workforce during the COVID-19 global epidemic. JAMA. 2020;323(15):1439-40. https://doi.org/10.1001/jama.2020.3972 PMid:32163102

9. Fawaz M, Anshasi $\mathrm{H}$, Samaha $\mathrm{A}$. Nurses at the front line of COVID-19: Roles, responsibilities, risks, and rights. Am J Trop Med Hyg. 2020;103(4):1341-2. https://doi.org/10.4269/ ajtmh.20-0650

PMid:32783796

10. Anizar. Occupational Safety and Health Engineering in Industry. Yogyakarta: Yogyakarta: Graha IImu; 2012.

11. Dermawan D. Buku Ajar Keperawatan Komunitas. Yogyakarta: Gosyen Publishing; 2012. 
12. Istih SM, Wiyono J, Candrawati E. Relationship between unsafe action with work accident on nurse in panti waluya sawahan hospital. Nurs News (Meriden). 2017;2(2):337-48.

13. Primadianto D, Putri SK, Alifen RS. The effect of unsafe acts and unsafe conditions on construction work accidents. J Dimens Pratama Tek Sipil. 2018;7(1):77-84.

14. Irzal MK. Basics of Occupational Health and Safety. $1^{\text {st }}$ ed. Jakarta: Kencana; 2016

15. Michaels D, Wagner GR. Occupational safety and health administration (OSHA) and worker safety during the COVID-19 pandemic. JAMA. 2020;324(14):1389-90. https://doi. org/10.1001/jama.2020.16343

PMid:32936212

16. World Health Organization. Mask Use in the Context of COVID-19. Geneva: World Health Organization; 2020. p. 1-10.

17. Cui S, Jiang $Y$, Shi Q, Zhang L, Kong D, Qian M, et al. Impact of COVID-19 on psychology of nurses working in the emergency and fever outpatient: A cross-sectional survey. Risk Manag Healthc Policy. 2021;14:585-94. https://doi.org/10.2147/RMHP. S289782

PMid:33623449

18. Chen N, Zhou M, Dong X, Qu J, Gong F, Han Y, et al Epidemiological and clinical characteristics of 99 cases of 2019 novel coronavirus pneumonia in Wuhan, China: A descriptive study. Lancet. 2020;395(10223):507-13. https://doi.org/10.1016/ S0140-6736(20)30211-7

PMid:32007143

19. Annur CM. A Total of 2,029 Health Workers Died Due to Covid19; 2021. Available from: https://databoks.katadata.co.id/ datapublish/2021/09/15/sebanyak-2029-tenaga-kesehatanmeninggal-akibat-covid-19. [Last accessed on 2021 Nov 15].

20. Notoatmodjo S. Health Research Methodology. Jakarta: PT Rhineka Cipta; 2012.
21. Debora V, Oktarlina RZ, Perdani RR. The differences in level knowledge, perceptions, and experience to use of generic drug in medical and non medical students university of Lampung. Majority. 2018;7(2):24-33.

22. Husain F, Lalintia NM, Ardhaneswari PM, Febrianti W. Nurse behavior in the implementation of K3RS management during the Covid-19 pandemic. J Manaj Asuhan Keperawatan. 2021;5(2):90-6.

23. Jackson D, Bradbury-Jones C, Baptiste D, Gelling L, Morin K, Neville S, et al. Life in the pandemic: Some reflections on nursing in the context of COVID-19. J Clin Nurs. 2020;29(13-14):2041-3. https://doi.org/10.1111/jocn.15257 PMid:32281185

24. Situmorang $\mathrm{H}$. Experience in applying infection control management at $\mathrm{H}$. Adam Malik Hospital of Medan. J Persat Perawat Nas Indones. 2018;3(1):24.

25. Stellman JM. The ILO encyclopedia of occupational health and safety: A multidisciplinary challenge. Int Labour Rev. 1998;137(3):410-8.

26. Fadli F, Safruddin S, Ahmad AS, Sumbara S, Baharuddin R. Factors affecting anxiety in health workers in efforts to prevent Covid-19. J Pendidik Keperawatan Indones. 2020;6(1):57-65.

27. Romiko R. Analysis of nurse compliance with infection prevention and control at Palembang Muhammadiyah Hospital. Masker Med. 2020;8(1):201-15.

28. Tukatman $T$, Sulistiawati $S$, Purwaningsih $P$, Nursalam $N$ Analysis of nurse's occupational health in managing patients in benyamin Guluh hospital Kolaka Regency. J Ners. 2015;10(2):343-7. http://dx.doi.org/10.20473/jn.v10i2.1405

29. Mulyatiningsih S. Determinants of Nurse Behavior in Patient Safety Inpatients at RSAU Dr. Esnawan Antariksa Jakarta. Jakarta: Universitas Indonesia; 2013. 